\title{
Purple Yam Extract (Dioscorea Alata L.) As Adjuvant Antihipertension Medicine for Postpartum Hipertension
}

\author{
Dina Hanifa*, Suharyo Hadisaputro, Supriyana, Bedjo Santoso \\ Politeknik Kesehatan Kemenkes Semarang \\ * hanifadina01@gmail.com
}

\begin{abstract}
One third of women who have hypertension in pregnancy will continue to have high blood pressure during the postpartum period. Postpartum hypertension has effects such as cardiovascular disorders to HELLP syndrome. Potential adjuvant pharmacological therapy is needed, one of them is purple yam extract which contains flavonoids and dioscorin to reduce blood pressure. This type of research is a quasi experiment with pre-post test with control group design. The research respondents consisted of 16 people treated with purple yam extract $320 \mathrm{mg} /$ day and nifedipine $10 \mathrm{mg} /$ day and 16 people were given nifedipin 10 $\mathrm{mg} /$ day for 14 days. The results of the study were the systolic blood pressure of the intervention group decreased by $28.12 \mathrm{mmHg}$ and the control group decreased by 8.94 $\mathrm{mmHg}$ with a p-value of 0,000 . The diastolic blood pressure of the intervention group decreased by $18.43 \mathrm{mmHg}$ and the control group decreased by $3.75 \mathrm{mmHg}$ with a p-value of 0,000 . The conclusion of this study is purple yam extract has the potential as an alternative therapy to reduce blood pressure in postpartum hypertension.
\end{abstract}

Keywords : Purple Yam Extract, Blood Pressure, Hypertension, Postpartum 


\section{STRADA Jurnal Ilmiah Kesehatan}

DOI: $10.30994 /$ sjik.v9i2.363

ISSN: 2252-3847 (print); 2614-350X (online)

Vol.9 No.2 November 2020 Page.443-449

\section{BACKGROUND}

One third of women who have hypertension in pregnancy or pre-eclampsia will continue to have high blood pressure during the postpartum period even have a normal blood pressure in early labor (Smith, Waugh and Nelson-piercy, 2013). Postpartum hypertension has effects such as hypofibrinogemia, cardiovascular disorders, liver necrosis, pulmonary edema, brain hemorrhage, acute kidney injury, HELLP syndrome (Hemolysis Elevated Liver enzyme Low Platelet count) (Ghuman et al., 2009), (Smith, Waugh and Nelson-piercy, 2013), (Nzelu et al., 2017).

The World Health Organization states the number of maternal deaths as many as 295,000 women caused by hypertension came second at $14 \%$ after bleeding $27.1 \%$ (Say et al., 2006). Likewise with the trend of the causes of MMR in Indonesia has experienced a shift with increasing cases of pregnancy hypertension and postpartum hypertension from year to year (Kemenkes RI, 2018).

Handling of maternal postpartum hypertension aims to prevent complications can occur through pharmacological and non-pharmacological treatment. Pharmacological treatment that is often used by health workers is the administration of nifedipine $10 \mathrm{mg}$. Some patients also require combination pharmacological therapy for hypertension so that they can achieve normal blood pressure targets, but combination therapy can increase treatment costs and reduce patient compliance due to the large amount of drugs that must be consumed (Ismalia et al., 2016).

Therefore non-pharmacological therapy is needed as an adjuvant to antihypertensive drugs to reduce blood pressure, one of which is the provision of purple yam extract (Dioscorea alata $L$.) which contains bioactive compounds namely dioscorin and flavonoids which have activities as antihypertensive and antioxidants that work to inhibits ACE (Angiotensin Converting Enzym) (Prasetya et al., 2016). Some studies also show that dioscorin can reduce blood pressure or antihypertensive effects both in vivo and in vitro (Liu et al., 2009a). Dioscorin in certain doses has the effectiveness in inhibiting angiotensinconverting enzyme (ACE) up to 50\% when compared to captopril which is a standard drug for hypertension (Hsu et al., 2002).

Based on the above background, the effect of purple yam has a role in reducing blood pressure so that the potential of purple yam extract (Dioscorea alata L.) as an adjuvant to antihypertensive drugs to change blood pressure in postpartum hypertensive mothers.

\section{METHODS}

This research uses Quasi Experiment research with pre and post test with control group design. This study aims to analyze the potential of purple yam extract (Dioscorea alata $L$.) as an alternative therapy for reducing blood pressure in postpartum hypertension. The sample consisted of 16 intervention groups and 16 control groups. Each group was given the intervention for 14 days. The intervention group was given purple yam extract (a daily dose of $320 \mathrm{mg}$ ) plus nifedipine (a daily dose of $10 \mathrm{mg}$ ), while the control group was only given nifedipine with a daily dose of $10 \mathrm{mg}$. Blood pressure were measured everyday from pretest until postest. The instrument used for primary blood pressure data collection is the observation sheet. Data were analyzed by means of the Independent $\mathrm{T}$ test parametric test to determine differences between groups on systolic and diastolic blood pressure variables. 


\section{STRADA Jurnal Ilmiah Kesehatan}

DOI: $10.30994 /$ sjik.v9i2.363

ISSN: 2252-3847 (print); 2614-350X (online)

Vol.9 No.2 November 2020 Page.443-449

\begin{tabular}{|c|c|c|c|c|c|}
\hline \multicolumn{6}{|c|}{$\begin{array}{l}\text { RESULTS } \\
\text { Univariate analysis } \\
\text { Tabel 1. Distribution of Characteristics of Respondents by Age, Parity, Type of } \\
\text { Labor, History Hypertension in Pregnancy, Family History and Stress Level }\end{array}$} \\
\hline \multirow{2}{*}{ Characteristics } & \multicolumn{2}{|c|}{ Intervention Group $(n=16)$} & \multicolumn{2}{|c|}{ Control Group $(n=16)$} & \multirow{2}{*}{$* p$} \\
\hline & $\mathbf{N}$ & $\%$ & $\mathbf{N}$ & $\%$ & \\
\hline Age & & & & & 0,504 \\
\hline$\leq 20$ & - & - & - & - & \\
\hline $21-35$ & 13 & 81,3 & 8 & 50 & \\
\hline$>35$ & 3 & 18,8 & 8 & 50 & \\
\hline Parity & & & & & 0,629 \\
\hline Primipara & 8 & 50 & 7 & 43,8 & \\
\hline Multipara & 8 & 50 & 9 & 56,3 & \\
\hline Grandemultipara & - & - & - & - & \\
\hline Type of Labor & & & & & 0,686 \\
\hline Normal Birth & 10 & 62,5 & 5 & 31,3 & \\
\hline $\mathrm{SC}$ & 6 & 37,5 & 11 & 68,8 & \\
\hline History in Pregnancy & & & & & 0,084 \\
\hline There & 8 & 50 & 9 & 56,3 & \\
\hline Nothing & 8 & 50 & 7 & 43,8 & \\
\hline Family History & & & & & 0,408 \\
\hline There & 5 & 31,3 & 5 & 31,3 & \\
\hline Nothing & 11 & 68,8 & 11 & 68,8 & \\
\hline Stress Level & & & & & 0,697 \\
\hline Normal & 12 & 75 & 11 & 68,8 & \\
\hline Mild & 3 & 18,8 & 4 & 25 & \\
\hline Moderate & 1 & 6,3 & 1 & 6,3 & \\
\hline Severe & - & - & - & - & \\
\hline Extremely severe & - & - & - & - & \\
\hline
\end{tabular}

*Homogenity

Table 1 shows frequency distribution of respondents. The age variable describes the highest age at the age of $21-35$ is 13 respondents $(81.3 \%)$ in the intervention group, while the control group has the same number at the age 21-35 and >35 years age groups that is 8 respondents $(50 \%)$. The parity variable describes respondents with the same number of birth categories of 8 respondents $(50 \%)$ primipara and 8 respondents $(50 \%)$ multiparara in the intervention group, while in the control group most of the respondents had the category of multipara births namely 9 respondents $(56.3 \%)$.

The type of labor level variable shows the highest type is normal birth of 10 respondents $(62.6 \%)$ in the intervention group and in the control group most of the SC is 11 respondents $(68.8 \%)$. The pregnancy history variable shows the highest respondents in the intervention group there were respondents with a history of pregnancy hypertension as many as 8 respondents $(50 \%)$ and 8 respondents with no history of pregnancy, whereas in the control group most of the respondents had a history of pregnancy hypertension that was 9 respondents $(56.3 \%)$. The family hypertension history variables describe the highest of respondents there is no family history of hypertension, namely 11 respondents $(68.8 \%)$ in the each group. The stress level variable most of the respondents had normal stress 


\section{STRADA Jurnal Ilmiah Kesehatan}

DOI: $10.30994 /$ sjik.v9i2.363

ISSN: 2252-3847 (print); 2614-350X (online)

Vol.9 No.2 November 2020 Page.443-449

levels, namely 12 respondents $(75 \%)$ in the intervention group and 11 respondents $(68.8 \%)$

in the control group.

Bivariate Analysis Systolic

Tabel 2. Differences in Systolic Blood Pressure Values Between The Intervention and Control Group

\begin{tabular}{lccc}
\hline \multirow{2}{*}{ Systolic Blood Pressure } & \multicolumn{2}{c}{ Mean \pm SD } & \multirow{2}{*}{ p-value } \\
\cline { 2 - 3 } & Intervension & Control & 0,888 \\
Pre test & $149,81 \pm 5,822$ & $149,50 \pm 6,623$ & 0,929 \\
Post test 1 & $149,44 \pm 5,727$ & $149,25 \pm 6,061$ & 0,631 \\
Post test 2 & $147,94 \pm 6,038$ & $149,06 \pm 7,028$ & 0,133 \\
Post test 3 & $145,00 \pm 6,282$ & $148,25 \pm 5,615$ & 0,019 \\
Post test 4 & $143,44 \pm 4,885$ & $148,19 \pm 5,879$ & 0,004 \\
Post test 5 & $141,13 \pm 5,608$ & $147,50 \pm 6,066$ & 0,009 \\
Post test 6 & $140,81 \pm 6,134$ & $147,38 \pm 7,108$ & 0,001 \\
Post test 7 & $136,94 \pm 7,767$ & $146,38 \pm 6,927$ & 0,000 \\
Post test 8 & $134,13 \pm 8,049$ & $145,81 \pm 6,167$ & 0,000 \\
Post test 9 & $131,75 \pm 7,672$ & $145,69 \pm 5,301$ & 0,000 \\
Post test 10 & $129,00 \pm 8,140$ & $145,44 \pm 6,683$ & 0,000 \\
Post test 11 & $127,69 \pm 7,436$ & $145,06 \pm 7,602$ & 0,000 \\
Post test 12 & $126,31 \pm 7,427$ & $144,94 \pm 6,465$ & 0,000 \\
Post test 13 & $125,06 \pm 6,875$ & $144,13 \pm 7,676$ & 0,000 \\
Post test 14 & $122,44 \pm 7,780$ & $142,56 \pm 6,449$ & 0,000 \\
Post test 15 & $121,69 \pm 7,245$ & $140,56 \pm 5,796$ & 0,000 \\
$\Delta$ Pre-Post 15 & $28,12 \pm 8,205$ & $8,94 \pm 7,945$ & \\
\hline
\end{tabular}

* Independent T-test

Based on table 2, the results of the Independent T-test statistical test showed a p-value $<0.05$ on the day 4 measurement ( $\mathrm{p}$-value $=0.019<0.05$ ), meaning that there were significant differences between changes systolic blood pressure in intervention groups and control group. However, the results showed that on the day 7 the systolic blood pressure clinically was effective, because blood pressure was starting at $<140 \mathrm{mmHg}$.

Bivariate Analysis Diastolic

Tabel 3. Differences in Diastolic Blood Pressure Values Between The Intervention and Control Group

\begin{tabular}{lccc}
\hline \multirow{2}{*}{ Diastolic Blood Pressure } & \multicolumn{2}{c}{ Mean \pm SD } & \multirow{2}{*}{ p-value } \\
\cline { 2 - 3 } & Intervension & Control & \\
\hline Pre test & $95,31 \pm 2,960$ & $95,50 \pm 2,852$ & 0,856 \\
Post test 1 & $94,44 \pm 3,245$ & $94,50 \pm 2,852$ & 0,333 \\
Post test 2 & $93,88 \pm 3,631$ & $94,06 \pm 3,172$ & 0,877 \\
Post test 3 & $93,00 \pm 3,795$ & $94,00 \pm 3,688$ & 0,456 \\
Post test 4 & $91,81 \pm 3,692$ & $94,00 \pm 4,033$ & 0,120 \\
Post test 5 & $90,06 \pm 3,660$ & $93,94 \pm 3,549$ & 0,005 \\
Post test 6 & $89,19 \pm 4,037$ & $93,94 \pm 3,549$ & 0,001 \\
Post test 7 & $88,13 \pm 4,455$ & $93,69 \pm 3,877$ & 0,001 \\
Post test 8 & $86,94 \pm 4,404$ & $93,69 \pm 3,877$ & 0,000
\end{tabular}




\section{STRADA Jurnal Ilmiah Kesehatan}

DOI: $10.30994 /$ sjik.v9i2.363

ISSN: 2252-3847 (print); 2614-350X (online)

Vol.9 No.2 November 2020 Page.443-449

\begin{tabular}{llll}
\hline Post test 9 & $85,69 \pm 4,483$ & $93,63 \pm 2,802$ & 0,000 \\
Post test 10 & $84,13 \pm 4,588$ & $93,50 \pm 3,204$ & 0,000 \\
Post test 11 & $82,88 \pm 4,272$ & $93,44 \pm 3,651$ & 0,000 \\
Post test 12 & $81,81 \pm 4,888$ & $92,50 \pm 3,386$ & 0,000 \\
Post test 13 & $81,81 \pm 4,888$ & $92,50 \pm 3,386$ & 0,000 \\
Post test 14 & $76,88 \pm 6,065$ & $91,75 \pm 4,851$ & 0,000 \\
Post test 15 & $76,88 \pm 6,065$ & $91,75 \pm 4,851$ & 0,000 \\
$\Delta$ Pre-Post 15 & $18,44 \pm 6,408$ & $3,75 \pm 5,222$ & 0,000 \\
\hline
\end{tabular}

* Independent T-test

Based on table 3, the results of the Independent T-test statistical test showed a $\mathrm{p}$-value $<0.05$ on the day 5 measurement ( $\mathrm{p}$-value $=0.005<0.05$ ), meaning that there were significant differences between changes diastolic blood pressure in groups intervention and control group. However, the results showed that on the day 6 that diastolic blood pressure clinically was effective, because blood pressure was starting at $<90 \mathrm{mmHg}$.

\section{DISCUSSION}

The results of the analysis of differences in changes in systolic and diastolic blood pressure in the intervention group and the control group can be seen in Tables 2 and 3, which are the most systolic and diastolic blood pressure decreased in the intervention group, namely systolic $28.12 \mathrm{mmHg}$ and diastolic $18.44 \mathrm{mmHg}$. Whereas the control group was decrease in systolic $8.94 \mathrm{mmHg}$ and diastolic $3.75 \mathrm{mmHg}$. The mean difference in systolic blood pressure between the intervention and control groups was $19.18 \mathrm{mmHg}$ with a p-value of 0,000 . While the diastolic blood pressure mean difference between the intervention and control groups was $14.69 \mathrm{mmHg}$ with a p-value of 0,000 .

The results of blood pressure analysis obtained are supported by research conducted by the Fourth Internal Medicine Department on calcium channel blockers having minimal metabolic effects. Symptoms in postpartum hypertensive mothers who consume nifedipine are usually mild, including dizziness, nausea, redness of the skin, headaches and palpitations. A more serious but rare effect is hypotension (Burnier, 2017).

The National Center of Complementary and Alternative Medicine of the National Institute of Health classifies various kinds of treatment and therapy systems into 5 categories, one of which is Biological Base Therapies (BBT) which is a type of complementary therapy using natural ingredients. The use of natural ingredients as traditional medicine can be a supporting alternative with fewer side effects compared to the available drugs (Sharma et al., 2017).

The use of alternative drugs needs to be considered given the side effects that can be caused in consuming nifedipine. One of them by using purple yam extract. Purple yam is one of the local plants in Indonesia. Purple yam is included in the Dioscorea family, which is a hypotensive agent for flavonoids and dioscorin.

Flavonoids function to protect endothelial function and help reduce blood pressure through the effects of hypotension by inhibiting the activity of ACE and as a diuretic. Flavonoids inhibit the action of ACE which plays an important role in the change of angiotensin I to angiotensin II as a cause of narrowing of blood vessels and raising blood pressure (Nadila, 2014). Dioscorin also has the ability to inhibit angiotensin converting enzyme (ACE) which triggers an increase in blood pressure (Hsu et al, 2002; Liu et al, 2009b). Purple yam extract that given to postpartum hypertension in the study contained $1222,731 \mathrm{mg} / 100$ gram flavonoids and $33.817 \%$ dioscorin. 


\section{STRADA Jurnal Ilmiah Kesehatan}

DOI: $10.30994 /$ sjik.v9i2.363

ISSN: 2252-3847 (print); 2614-350X (online)

Vol.9 No.2 November 2020 Page.443-449

Various studies on the benefits of purple yam (Dioscorea alata L.) have been carried out, but only a few have examined the relationship with hypertension, several studies mentioned include studies conducted by Liu et al (2009), studies on mice models of hypertensive given water purple yam extracts and purple yam powders once a day using a sonde for 1 month. Administration of $40 \mathrm{mg} / \mathrm{Kg}$ powder extract showed a $32.4 \mathrm{mmHg}$ systolic reduction and a diastolic reduction of $31.9 \mathrm{mmHg}$ at $6-8$ hours after administration (Liu et al., 2009a).

The results of the bivariate analysis of the study stated that the pharmacological therapy of nifedipine $10 \mathrm{mg}$ and purple yam extracts $320 \mathrm{mg}$ as an adjuvant had a higher potential effect than the pharmacological therapy of nifedipine $10 \mathrm{mg}$ in reducing systolic and diastolic blood pressure in postpartum hypertension. Purple yam extract in this study acts as a potentiation with nifedipine given together with different actions, but has a greater effect on patients if given together rather than each effect separately.

\section{CONCLUSION}

The providing of purple yam extract (Dioscorea Alata L.) dose $320 \mathrm{mg}$ for 14 days in postpartum hypertension who get nifedipine $10 \mathrm{mg} / \mathrm{day}$ has the potential adjuvant to decreasing systolic and diastolic blood pressure.

This research can be used as a reference regarding nonpharmacological therapy accompanying antihypertensive drugs to help reduce maternal blood pressure in postpartum period and the development of midwifery to improve the quality of providing midwifery care in post natal care midwifery services.

\section{REFERENCE}

Burnier, M. (2017). Drug adherence in hypertension. Pharmacological Research, 125, 142-149.

Ghuman, N., Rheiner, J., Tendler, B. E., \& White, W. B. (2009). Hypertension in the Postpartum Woman: Clinical Update for the Hypertension Specialist. The Journal of Clinical Hypertension, 11(12), 726-733.

Hsu, F. H., Y. H. Lin, M. H. Lee, C. L. Lin, and W. C. Hou. (2002). Both Dioscorin, The Tuber Storage Protein of Yam (Dioscorea alata CV Tainong No. 1), and its Peptic Hydrolysates Exhibited Angiostensin Converting Enzyme Inhibitory Activities. J. Agric.Food Chem, 50, 6109-6113.

Ismalia N, Zuraida R. (2016). Effect Tomato (Lycopersion esculentum Mill) for Decreasing High Blood Pressure. MAJORITY, 5(4), 107-111.

Kementrian Kesehatan Republik Indonesia. Profil Kesehatan Indonesia 2017. (2018). Jakarta: Kementerian Kesehatan Republik Indonesia.

Liu, Y.H., Lin, Y.-S., Liu, D.-Z., Han, C.-H., Chen, C.-T., Fan, M., \& Hou, W.-C. (2009a). Effects of Different Types of Yam (Dioscorea alata) Products on the Blood Pressure of Spontaneously Hypertensive Rats. Bioscience, Biotechnology, and Biochemistry, 73(6), 1371-1376.

Liu, Y. M. and K. W. Lin. (2009b). Antioxidative ability, dioscorin stability, and the quality of yam chips from various yam species as affected by processing method. Journal of Food Science, 74(2), C118-C125.

Nadila F. (2014). Antihypertensive Potential of Chayote Fruit Extract for 


\section{STRADA Jurnal Ilmiah Kesehatan}

DOI: $10.30994 /$ sjik.v9i2.363

ISSN: 2252-3847 (print); 2614-350X (online)

Hypertension Treatment. J Majority, 3(7), 34-38.

Nzelu, D. (2018). Dumitrascu-Biris, D., Hunt, K. F., Cordina, M., \& Kametas, N. A. Pregnancy outcomes in women with previous gestational hypertension: A cohort study to guide counselling and management. Pregnancy Hypertension, 12, 194200.

Prasetya, Estiasih Teti, Nugrahini Nur Ida Panca. (2016). Potensi Tepung Ubi Kelapa Ungu dan Kuning. Jurnal Pangan dan Agroindustri, 4(2), 468-473.

Say L, Chou D, Gemmill A, Tunçalp Ö, Moller AB, Daniels JD, et al. (2014). Global Causes of Maternal Death: A WHO Systematic Analysis. Lancet Global Health, 2(6), e323-e333.

Sharma KJ GN. (2017). Oral Labetalol Compared to Oral Nifedipin for Postpartum Hypertension: A randomized controlled trial. Hypertension in Pragnancy, 36(1), 44-47.

Smith, M., Waugh, J., \& Nelson-Piercy, C. (2013). Management of postpartum hypertension. The Obstetrician \& Gynaecologist. 15(1), 45-50. 